\title{
Disappearance of infused phytate from the large intestine of dairy heifers
}

\author{
P. P. Ray, ${ }^{* 1}$ C. Shang, † R. E. Pearson, ${ }^{*}$ and K. F. Knowlton* \\ ${ }^{*}$ Department of Dairy Science, and \\ †Department of Crop and Soil Environmental Sciences, Virginia Polytechnic Institute and State University, Blacksburg 24061
}

\begin{abstract}
The objective of this study was to investigate the disappearance of phytate from the large intestine of dairy heifers. Uncertainty about the availability of phosphorus $(\mathrm{P})$ in different feeds may limit implementation of dietary strategies to reduce fecal $\mathrm{P}$ excretion by dairy cows. Increased understanding of the dynamics of phytate degradation and disappearance of $\mathrm{P}$ in the large intestine may improve prediction of intestinal $\mathrm{P}$ digestion and absorption. Eight ruminally- and ileallycannulated crossbred dairy heifers were used in two 4 $\times 4$ Latin square designs with 9 -d periods, including $3 \mathrm{~d}$ of washout. All heifers were fed a high-forage diet containing $0.14 \% \mathrm{P}$ throughout the study. Ytterbiumlabeled corn silage and Co-EDTA were dosed to the rumen 4 times daily as particulate and liquid phase markers, respectively, to measure ileal digesta flow. On d 4 to 7 of each period, each heifer was infused ileally with $0,5,15$, or $25 \mathrm{~g} / \mathrm{d}$ of phytate (phytic acid) in solution and total fecal collection was conducted. When infusion ceased (d 8 and 9) ileal digesta was sampled to measure $\mathrm{P}$ flow to the ileum from the basal diet. Feed, digesta, and feces were dried, ground, and analyzed for phytate $\mathrm{P}$, inorganic $\mathrm{P}$, and total $\mathrm{P}$ using high performance ion chromatography, inductively coupled plasma atomic emission spectroscopy, and the molybdovanadate yellow method, respectively. Phytate degradation in the large intestine was observed but was not complete, and the amount of infused phytate did not influence the degradability of phytate. Fecal excretion of total $\mathrm{P}$ increased with increasing total $\mathrm{P}$ infused. The slope coefficient for ileal P flow (dietary only) to feces was $0.56 \pm 0.26$ (mean $\pm \mathrm{SE}$ ), whereas the slope coefficient for infused $\mathrm{P}$ was $0.75 \pm 0.13$. These indicate net absorption of $\mathrm{P}$ from the large intestine and greater disappearance of $\mathrm{P}$ from dietary $\mathrm{P}$ flowing to the ileum than from the infused pure phytate (44 vs. 25\%). This data will support mechanistic modeling efforts to im-
\end{abstract}

Received January 20, 2012.

Accepted June 22, 2012

${ }^{1}$ Corresponding author: drray@vt.edu prove prediction of $\mathrm{P}$ digestion, allowing more accurate estimation of $\mathrm{P}$ bioavailability in feeds.

Key words: phytate digestion, phosphorus absorption, large intestine, dairy heifer

\section{INTRODUCTION}

In high-producing dairy cows, $\mathrm{P}$ plays an important role in maintaining production and performance. Absorbed $\mathrm{P}$ is constantly secreted in milk irrespective of dietary P intake (Cohen, 1980; Knowlton et al., 2001). More than $80 \%$ of the total body $\mathrm{P}$ is present in bone. Bone mineral resorption plays a key role in regulating blood $\mathrm{P}$, and replenishment of bone $\mathrm{P}$ is critical to maintain animal performance and production (Cohen, 1980; Wu et al., 2001; Peterson et al., 2005). The salient physiological characteristic of salivary $\mathrm{P}$ recycling in ruminants demands continuous and sufficient dietary P supply (Horst, 1986; Valk et al., 2002). In ruminants offered P-deficient diets, feed intake was depressed and ruminal digestion impaired (Komisarczuk et al., 1987; Durand and Komisarczuk, 1988). Reduced ATP production and transfer in the rat myocardium during $\mathrm{P}$ depletion reflects the importance of the role of $\mathrm{P}$ in energy production and transfer, and similar relationships were observed in ruminants fed P-deficient diets (Riddell et al., 1933; Louw, 1979; Brautbar et al., 1982).

Phosphorus losses from farms, a problem exacerbated by excess dietary $\mathrm{P}$, contribute to eutrophication. For this reason and because of increasing cost due to depletion of natural sources of phosphate (Leng, 2008), the use of inorganic P $(\mathbf{P i})$ supplements has been reduced for last few decades. Dietary $\mathrm{P}$ content in dairy rations in the United States typically exceeds the amount recommended by the NRC (Dou et al., 2003), making $\mathrm{P}$ supplementation unnecessary. But, care needs to be taken in formulation of low-P diets to be sure sufficient $\mathrm{P}$ is supplied both for the rumen microbes and the cow. Current NRC (2001) recommendations for dietary P supply are based on the calculation accounting for the requirement of absorbed $\mathrm{P}$ for milk production, maintenance, growth, and reproduction. Specific absorption coefficients were assigned for each source of $\mathrm{Pi}$, but fixed values were assigned for forages (0.64) and con- 
centrates (0.70) and these are based on relatively sparse research. The single availability coefficient for forages and for grains ignores the observation that ruminal $\mathrm{P}$ availability is greatly influenced by type of feed or feed processing (Bravo et al., 2003; Kincaid et al., 2005). Using these fixed absorption coefficients may limit accurate calculation of dietary $\mathrm{P}$ supply.

Ruminants are more efficient than nonruminants in extracting $\mathrm{P}$ from phytate, the major form of $\mathrm{P}$ in grains and cereals. Although the expression of the enzyme phytase by ruminal microorganisms allows ruminants to hydrolyze phytate (Nelson et al., 1976; Clark et al., 1986; Morse et al., 1992), phytate degradation by ruminants may be incomplete in certain dietary situations (Park et al., 1999; Park et al., 2000; Bravo et al., 2002). Grain type, processing of feed ingredients, and supplementation with exogenous phytase have also been shown to influence ruminal phytase activity (Yanke et al., 1998) or phytate hydrolysis (Park et al., 2000; Bravo et al., 2003; Kincaid et al., 2005). In lactating cows, high phytate intake with feeding of highconcentrate diets and fast rate of digesta passage due to high DMI may result in flow of phytate $\mathrm{P}$ to the lower digestive tract. The large intestinal degradation of phytate has been widely investigated in monogastrics (Williams and Taylor, 1985; Matsui et al., 1999; Marounek et al., 2003) but data describing the amount and fate of phytate flowing to the large intestine in ruminants are scarce. Large intestinal phytate degradation is attributed primarily to microbial phytase activity. Though the bacterial population in the large intestine is not exactly same as the rumen, some species are in common (Maki and Picard, 1965; Yanke et al., 1998) and the total viable count of bacteria per gram of wet weight in cecal and colon digesta collectively was the same as in ruminal digesta (Edwards et al., 2005). Therefore, phytate digestion in the large intestine seems likely. In sheep fed a 50:50 forage:concentrate diet, daily passage of inositol phosphates (IP) through the upper large intestine was less than through the small intestine, likely due to microbial phytase activity in sheep large intestine (Park et al., 2002). The release of Pi due to phytate hydrolysis is of nutritional significance only if $\mathrm{P}$ is absorbed from the large intestine. Although the extent is highly variable, disappearance of $\mathrm{P}$ from the ruminant large intestine has been reported (Scharrer, 1985; Breves and Schroder, 1991).

We hypothesized that phytate entering the large intestine of ruminants can be hydrolyzed, and the released $\mathrm{Pi}$ absorbed. The objective of this study was to quantify phytate $\mathrm{P}$ degradation in the large intestine of dairy heifers and to estimate the disappearance of $\mathrm{P}$ from the large intestine.

\section{MATERIALS AND METHODS}

\section{Animals and Experimental Design}

Eight crossbred [Swedish Red or Brown Swiss $\times$ (Holstein $\times$ Jersey)] heifers, averaging $420 \mathrm{~kg}$ of BW, were fitted surgically with a half T-type Tygon ileal cannula (5 to $6 \mathrm{~cm}$ anterior to ileocecal junction) and a ruminal cannula (Bar Diamond Inc., Parma, ID) 60 and $21 \mathrm{~d}$ before the experiment, respectively. All surgeries were conducted aseptically using local anesthesia. Ileal cannulas were checked daily to ensure fixed position and cleaned twice per week to prevent local infection.

Heifers were housed in a freestall barn with constant access to water and fed once daily using Calan doors. A high-forage diet (91\% forage; Table 1) was formulated to contain very low total $\mathrm{P}(0.14 \%$ of dietary $\mathrm{DM})$ to minimize the amount of organic $\mathrm{P}$ reaching the ileum, allowing unconfounded measurement of disappearance of the infused phytate. Diets were formulated to meet NRC (2001) recommendations for heifers weighing 420 $\mathrm{kg}$ for all nutrients except P. Feed was offered ad libitum during a 21-d diet acclimation period. To maintain constant DM proportions of forage and concentrate in diet, the DM content of corn silage was measured weekly and the amount of forage adjusted accordingly. After $21 \mathrm{~d}$ of diet acclimation, heifers were moved to individual tie-stalls in a metabolism unit for infusion and sampling.

Heifers were randomly assigned to 1 of 4 treatment sequences in a duplicated Latin square design with four

Table 1. Composition of basal diet fed to 8 crossbred heifers

\begin{tabular}{|c|c|}
\hline Composition & $\begin{array}{c}\% \text { of } \\
\text { dietary DM }\end{array}$ \\
\hline \multicolumn{2}{|l|}{ Ingredient } \\
\hline Barley straw & 38.3 \\
\hline Corn silage & 14.7 \\
\hline Beet pulp, dried & 38.6 \\
\hline Cane molasses, dehydrated & 4.98 \\
\hline Slow release $\mathrm{NPN}^{1}$ & 2.72 \\
\hline Trace mineral mix $^{2}$ & 0.11 \\
\hline Selenium $90^{3}$ & 0.42 \\
\hline Vitamin ADE $\operatorname{mix}^{4}$ & 0.18 \\
\hline \multicolumn{2}{|l|}{ Nutrient } \\
\hline $\mathrm{CP}$ & 12.6 \\
\hline NDF & 54.4 \\
\hline $\mathrm{ADF}$ & 34.7 \\
\hline $\mathrm{P}$ & 0.14 \\
\hline Phytate $\mathrm{P}^{5}$ & 0.005 \\
\hline \multicolumn{2}{|c|}{${ }^{1}$ Optigen (Alltech Inc., Springfield, KY). } \\
\hline \multirow{2}{*}{\multicolumn{2}{|c|}{$\begin{array}{l}{ }^{2} \text { Contained } 37 \% \mathrm{Na}, 60 \% \mathrm{Cl}, 0.03 \% \mathrm{~K}, 0.3 \% \mathrm{Mg} \text {, and } 14 \% \mathrm{~S} \text {. } \\
{ }^{3} \text { Contained } 90 \mathrm{mg} \text { of Se per kilogram of DM. }\end{array}$}} \\
\hline & \\
\hline \multicolumn{2}{|c|}{$\begin{array}{l}{ }^{4} \text { Contained } 26,400 \mathrm{KIU} \text { of vitamin A; } 8,800 \mathrm{KIU} \text { of vitamin D; and } \\
44,000 \mathrm{IU} \text { of vitamin E per kilogram of DM. }\end{array}$} \\
\hline
\end{tabular}


9-d periods. Treatments were infusion of $0,5,15$, or 25 $\mathrm{g} / \mathrm{d}$ of phytate (phytic acid) in solution $(0,1.41,4.22$, and $7.04 \mathrm{~g}$ of $\mathrm{P} / \mathrm{d}$, respectively) in a total of $960 \mathrm{~mL} / \mathrm{d}$ $(40 \mathrm{~mL} / \mathrm{h})$ using an infusion pump (Ardus Medical Inc., Cincinnati, OH). Solutions of varying phytate $\mathrm{P}$ concentrations were prepared using $50 \%$ (wt/wt) phytic acid solution (Sigma-Aldrich Co., St. Louis, MO). The $\mathrm{pH}$ of infusion solutions were adjusted to neutral or mildly alkaline (7 to 8.1 ) before infusion.

A 7-d adjustment period to the metabolism stall was allowed before the start of the first period and then each period included $3 \mathrm{~d}$ of washout, $4 \mathrm{~d}$ of infusion, and $2 \mathrm{~d}$ of ileal sampling. During the washout periods, heifers were fed at 0600 and $1800 \mathrm{~h}$. During infusions, heifers were fed 4 times daily at 0600, 1200, 1800, and $2400 \mathrm{~h}$. On d 3 of each period, heifers were fitted with urinary catheters to prevent mixing of feces and urine. Heifers were observed for signs of illness and rectal temperatures were recorded daily.

Ytterbium-labeled corn silage and Co-EDTA were dosed daily as particulate and liquid-phase markers, respectively, to measure ileal digesta flow. Dried corn silage retained on the bottom sieve of the Penn State Particle Separator was labeled using $\mathrm{YbCl}_{3}$ solution by the method described by Harvatine et al. (2002). Lithium Co-EDTA was prepared by the method of Udén et al. (1980). Markers were mixed with rumen digesta 4 times daily throughout the study at a rate of $0.11 \mathrm{~g}$ of $\mathrm{Yb}$ or $\mathrm{Co} /$ heifer per day. All protocols and procedures were approved by the Virginia Tech Institutional Animal Care and Use Committee (Blacksburg).

\section{Sample Collection and Preparation}

Total mixed ration and feed refusals were sampled daily for the last $6 \mathrm{~d}$ of each period. Total fecal collection was conducted during the $4 \mathrm{~d}$ infusion (d 1 to 4 of each period). Every $24 \mathrm{~h}$, water was added (50\% of total feces weight) to increase feces homogeneity, and feces from each heifer was blended and sampled. When phytate infusion ceased (d 8 and 9), ileal digesta was collected through the ileal cannula 4 times per day $(0600,1200,1800$, and $2400 \mathrm{~h})$ to quantify $\mathrm{P}$ flow to the ileum from the basal diet. All samples were stored at $-20^{\circ} \mathrm{C}$ immediately following collection.

Frozen samples were later thawed, TMR samples composited by period, refusals composited by heifer $\times$ period, and ileal samples composited by heifer $\times$ day. Samples were oven dried (Wisconsin Oven; Memmert $\mathrm{GmbH} \&$ Co. KG, Schwabach, Germany) at $55^{\circ} \mathrm{C}$ until constant dry weight was achieved. Dried samples were ground through Wiley mill (1-mm screen; Arthur H. Thomas Co., Philadelphia, PA) and then through a Z grinder (0.2-mm screen; ZM 100 USA; Retsch GmbH,
Haan, Germany). Ground samples were stored in airtight containers.

\section{Sample Analysis}

Dried ground feed samples were analyzed for N, total P (AOAC, 1984), and NDF and ADF sequentially (Van Soest et al., 1991). Dried ground fecal samples were analyzed for $\mathrm{N}$ and total P (AOAC, 1984), and ileal digesta samples were analyzed for total P (AOAC, 1984). Ileal digesta samples were analyzed for $\mathrm{Yb}$ and Co using inductively coupled plasma atomic emission spectroscopy (Ciros Vision model; Spectro Analytical Instruments Inc., Mahwah, NJ).

Ileal and fecal samples were analyzed for inositol hexaphosphate (IP6) and lower inositol phosphates (IP5, IP4, IP3) following the method of Ray et al. (2012) except that a different high performance ion chromatography (HPIC) quantification approach was used. In brief, dried ground $(0.2-\mathrm{mm})$ samples were extracted using $0.25 M$ NaOH-0.05 $M$ EDTA and then alkaline extracts were acidified with $\mathrm{HCl}-\mathrm{HF}$ acid solution $(500$ $\mu \mathrm{L}$ of $6 \mathrm{M} \mathrm{HCl}$ and $1.2 \mathrm{M} \mathrm{HF}$ added to $5 \mathrm{~mL}$ of sample extract). Acidified extracts were stored overnight at $4^{\circ} \mathrm{C}$ and centrifuged at $30,000 \times g$ for $20 \mathrm{~min}$ at $4^{\circ} \mathrm{C}$. Clear supernatants were collected and passed through a methanol-conditioned $\mathrm{C}_{18}$ column (Sep-Pak Plus; Waters Corp., Milford, MA) and then through a $0.2-\mu \mathrm{m}$ IC membrane (PTFE filter; IC Millex-LG, Fisher, PA) into Dionex sample vials (Dionex Corp., Sunnyvale, CA) for HPIC analysis.

Chromatographic quantification of phytate (IP6) in clear sample extracts was achieved by HPIC (Dionex ICS 3000 with a Dionex $4 \times 50$ IonPac AG7 guard column and a $4 \times 250 \mathrm{~mm}$ IonPac AS7 analytical column; Dionex Corp.) using pH 4 elution and postcolumn reaction detection (Rounds and Nielsen, 1993; Kwanyuen and Burton, 2005; Leytem et al., 2008). Treated sample extracts $(50 \mu \mathrm{L})$ were injected into the column with an autoinjector. Phytate was eluted at $11.8 \mathrm{~min}$ with gradient elution (0.01 M methylpiperazine and $0.01 \mathrm{M}$ $\mathrm{NaNO}_{3}-0.01 M$ methylpiperazine) at a flow rate of 1 $\mathrm{mL} / \mathrm{min}$. Eluted phytate was mixed with Wade's reagent $\left(0.015 \% \mathrm{FeCl}_{3}+0.15 \%\right.$ sulfosalicylic acid solution) in a postcolumn reactor and detected using a UVvisible detector by monitoring absorbance at $500 \mathrm{~nm}$. Three IP6 standards $(6,30$, and $60 \mu \mathrm{g}$ of $\mathrm{P} / \mathrm{mL})$ were prepared using sodium salt of phytic acid (phytic acid, sodium salt hydrate powder; Sigma, St. Louis, MO).

The combination of alkaline extraction and HPIC quantification (Ray et al., 2012) makes possible quantification of phytate and the lower IP (IP3, IP4, and IP5) in ruminant digesta and fecal samples in a single HPIC run using the same sample extract after a com- 
mon postextraction cleanup process. The elution times for IP5, IP4, and IP3 were 10.5, 8.9, and $6.8 \mathrm{~min}$, respectively. Calculation of concentration of these lower IP used 2 secondary standards (mixtures of inositol phosphates), prepared by hydrolyzing $50 \mathrm{mg}$ of sodium phytate in $5 \mathrm{~mL}$ of $6 \mathrm{M} \mathrm{HCl}$ at $140^{\circ} \mathrm{C}$ for 1 and $2 \mathrm{~h}$, respectively. Pure standards of IP3, IP4, and IP5 were used to standardize the concentration-to-peak area ratio in the 2 secondary standards for lower IP and IP6. This ratio was used to calculate the concentrations of lower IP in unknown samples. The following equation was used to calculate lower IP concentration in samples:

$$
\mathrm{Cs}=\frac{\mathrm{Css}}{\mathrm{Ass}} \times \mathrm{As},
$$

where $\mathrm{Cs}=$ concentration of lower IP in sample extract, Css $=$ concentration of lower IP in secondary standard, Ass $=$ area of lower IP peak in secondary standard, and As $=$ area of lower IP peak in sample extract.

\section{Statistical Analysis}

All intake, excretion, and disappearance data were analyzed using PROC GLIMMIX in SAS (SAS Institute, 2002). The model included square, infusion dose, and period as fixed effects. For excretion and disappearance data, basal ileal flow was used as covariate. Data for 1 cow were excluded from the second period, as the cow was suffering from ruminal stasis. Polynomial contrasts were used to test the effect of infusing increasing quantities of phytate $(5,15$, and $25 \mathrm{~g} / \mathrm{d}$ ) on large intestinal phytate disappearance and fecal $\mathrm{Pi}$ excretion. Statistical significance was declared at $P<$ 0.05. Treatment means were separated using a multiple comparison test following the Tukey-Kramer method.

\section{RESULTS AND DISCUSSION}

\section{Diet Composition, Intake, and Digestibility}

As intended, quantified total $\mathrm{P}$ concentration in the diet averaged $0.14 \%$ (DM basis) across all periods (Table 1). Similarly, observed dietary phytate P concentration was very low (3.8\% of dietary total $\mathrm{P}$ ).

Heifers infused with saline or assigned phytate solution consumed an average of $7.7 \mathrm{~kg}$ of $\mathrm{DM} / \mathrm{d}$, and DMI, fecal DM, and apparent DM digestibility was similar for all treatment groups (Table 2). Average DM digestibility was $68.8 \%$, which is similar to the DM digestibility reported by others in growing heifers fed high-forage diets (Moody et al., 2007). Total P intake (average $10.8 \mathrm{~g} / \mathrm{d}$ ) was similar for all infusion groups, but fecal $\mathrm{P}$ increased with increased infusion of phytate $\mathrm{P}$ (Table 2).

\section{Intake, Ileal Flow, and Disappearance of Phytate from the Large Intestine}

Phytate $\mathrm{P}$ intake did not differ with treatment (Table 3). Dietary phytate $\mathrm{P}$ reaching the ileum was similar for all treatment groups (Table 3). On average, $68 \%$ of dietary phytate $\mathrm{P}$ was degraded in the rumen and small intestine. Several researchers have reported that ruminants hydrolyze the majority of feed phytate (78-100\%), with the rumen being the major site of phytate degradation (Clark et al., 1986; Morse et al., 1992; Kincaid et al., 2005). The digestion of phytate P in the rumen (and upper intestine) was comparatively low in this study (68\%). Park et al. (1999) reported $84 \%$ ruminal effective digestibility of phytate $\mathrm{P}$ when ruminal passage rate was $0.02 / \mathrm{h}$. Ruminal degradability of phytate $\mathrm{P}$ decreased to 69 and $57 \%$ when ruminal passage rate increased to 0.05 and $0.08 / \mathrm{h}$, respectively. The high-forage diet in this study would not seem to suggest a passage rate fast enough to reduce ruminal phytate P digestibility (Park et al., 1999). The relatively low ruminal phytate degradation in this study may instead be due to the effect of the type of diet (high forage) and dietary phytate content on ruminal phytase activity. Lower ruminal phytase activity was reported in steers fed all-hay diets than in those fed high-grain diets (Yanke et al., 1998), and lower phytase activity was observed in vitro (semicontinuous culture fermentor) with low-phytate than high-phytate diets (Godoy and Meschy, 2001). High dietary phytate is often the result of feeding a high-concentrate diet and phytate $\mathrm{P}$ hydrolysis was greater in dairy cows fed an $80 \%$ grain ( $0.38 \%$ phytate $\mathrm{P})$ diet as compared with cows fed a $52 \%$ grain $(0.24 \%$ phytate $\mathrm{P})$ diet $(99 \%$ vs. $78-85 \%$ phytate $\mathrm{P}$ hydrolysis; Morse et al., 1992; Kincaid et al., 2005). The low rumen $\mathrm{pH}$ resulting from high-grain diets creates an environment favoring efficient phytase activity (Yanke et al., 1999; Lan et al., 2011), and the endogenous phytase activity in many cereal grains contribute to phytate hydrolysis in high-grain diets (Viveros et al., 2000; Selle et al., 2003). The relatively low phytate hydrolysis in the rumen and upper intestine in this study supports these general observations that diet affects ruminal phytate hydrolysis, and also contradicts the conventional wisdom that phytate is completely hydrolyzable in the rumen.

A linear increase $(P=0.02)$ was observed in the amount of phytate that disappeared from the large intestine when the infused phytate level increased from 5 to $25 \mathrm{~g} / \mathrm{d}$, and daily fecal phytate $\mathrm{P}$ output increased 
Table 2. Dry matter intake, digestibility, total $\mathrm{P}$ intake, and fecal excretion in 8 crossbred heifers infused with different amounts of phytate $\mathrm{P}$

\begin{tabular}{lcccccc}
\hline & \multicolumn{9}{c}{ Infusion dose ${ }^{1}$} & & \\
\cline { 2 - 5 } Item & 0 & $\times$ & $3 \times$ & $5 \times$ & SEM & $P$-value \\
\hline DMI, kg/d & 7.48 & 7.60 & 7.36 & 8.28 & 0.54 & 0.65 \\
Fecal DM, kg/d & 2.12 & 2.37 & 2.33 & 2.65 & 0.24 & 0.52 \\
DM digestibility, $\%$ & 70.1 & 67.8 & 69.1 & 68.4 & 1.54 & 0.67 \\
P intake, g/d & 10.5 & 10.7 & 10.5 & 11.6 & 0.76 & 0.72 \\
Fecal P, g/d & $8.60^{\mathrm{a}}$ & $11.6^{\mathrm{ab}}$ & $13.7^{\mathrm{bc}}$ & $16.2^{\mathrm{c}}$ & 1.12 & $<0.0001$ \\
\hline
\end{tabular}

${ }^{a-c}$ Values within a row with different superscripts differ significantly $(P<0.05)$

${ }^{1}$ Daily infusion of phytate $\mathrm{P}$ to ileum $(\mathrm{g} / \mathrm{d}): 0=0, \times=5,3 \times=15,5 \times=25$.

with increased phytate $\mathrm{P}$ infusion to the ileum. However, phytate $\mathrm{P}$ disappearance (percentage of total supplied) from the large intestine was similar for all levels of phytate infusion (Table 3 ). Within the range of 5 to $25 \mathrm{~g} / \mathrm{d}$, the amount of phytate reaching the large intestine did not influence phytate degradation in the large intestine. This range of infusion was chosen as representative of the range associated with diets of lactating cows. For instance, a lactating Holstein cow with $680 \mathrm{~kg}$ of BW, $55 \mathrm{~kg} / \mathrm{d}$ of milk yield, and $30 \mathrm{~kg} / \mathrm{d}$ of DMI at 90 DIM would require $0.38 \%$ (DM basis) dietary $\mathrm{P}$ (NRC, 2001). If $70 \%$ of the dietary $\mathrm{P}$ is phytate $\mathrm{P}$, dietary phytate intake would be $80 \mathrm{~g} / \mathrm{d}$. Applying the foregut phytate digestibility observed in this study (68\% of consumed phytate $\mathrm{P}$ ), $25 \mathrm{~g}$ of phytate $\mathrm{P} / \mathrm{d}$ would reach the large intestine. These assumptions are extreme in terms of dietary phytate offered (extremely high) and foregut phytate hydrolysis (probably lower than would be observed in a high-phytate diet), and still the amount of phytate reaching the large intestine was within the upper limit of infused phytate into the large intestine in this study.

Although ruminal phytate hydrolysis does appear to be influenced by type of diet and feed processing method, a fixed value for large intestinal phytate hydrolysis can probably be used in estimating $\mathrm{P}$ availability from phytate P. In this study, the average disappearance of phytate $\mathrm{P}$ from the large intestine was $15 \%$ of the total phytate entering the large intestine (Table 3 ). This is similar to the $19 \%$ of phytate inflow digested between the upper and lower large intestine of sheep fed a $50 \%$ forage diet (Park et al., 2002). In that study, more than $10 \%$ of total dietary inositol phosphate was not digested. In the present study, considering $68 \%$ phytate hydrolysis in the rumen and then $15 \%$ hydrolysis of phytate entering the large intestine, total-tract phytate degradation would be $73 \%$, rendering $27 \%$ undigested and excreted in the feces. Combined, the results from this study and from the study by Park et al. (2002) indicate that large intestinal phytate degradation contributes to the overall digestibility of phytate but ruminal phytate hydrolysis is the key regulatory factor.

Large intestinal phytate degradation in sheep is considered to be due to the microbial phytase activity in the large intestine in ruminants (Park et al., 2002) and also in rodents and other nonruminants (Wise and Gilburt, 1982; Matsui et al., 1999). The microbial population in the large intestine is similar to that in the rumen (Maki and Picard, 1965; Hoover, 1978). Moreover, various species of Bacillus have been detected in the cecum and colon of cows and steers, and Bacillus strains have phytase capability (Joseph and Raj, 2007). The phytase activity in the large intestine must be less efficient than in the rumen, as less than $20 \%$ of influent phytate was digested in the large intestine in this study and in the sheep study by Park et al. (2002). Likely,

Table 3. Effect of ileal phytate infusion on disappearance of phytate from the large intestine of 8 crossbred heifers

\begin{tabular}{|c|c|c|c|c|c|c|}
\hline \multirow[b]{2}{*}{ Item } & \multicolumn{4}{|c|}{ Infusion dose $\mathrm{e}^{1}$} & \multirow[b]{2}{*}{ SEM } & \multirow[b]{2}{*}{$P$-value } \\
\hline & 0 & $x$ & $3 \times$ & $5 \times$ & & \\
\hline Phytate infused, g/d & $0.00^{\mathrm{a}}$ & $1.02^{\mathrm{b}}$ & $3.08^{\mathrm{c}}$ & $5.03^{\mathrm{d}}$ & 0.13 & $<0.0001$ \\
\hline Fecal phytate, $\mathrm{g} / \mathrm{d}$ & $0.12^{\mathrm{a}}$ & $1.05^{\mathrm{b}}$ & $2.63^{\mathrm{c}}$ & $4.30^{\mathrm{d}}$ & 0.28 & $<0.0001$ \\
\hline Phytate disappearance, $\mathrm{g} / \mathrm{d}$ & $0.05^{\mathrm{a}}$ & $0.15^{\mathrm{ab}}$ & $0.62^{\mathrm{b}}$ & $0.62^{\mathrm{b}}$ & 0.14 & $<0.01$ \\
\hline
\end{tabular}

${ }^{\mathrm{a}-\mathrm{d}}$ Values within a row with different superscripts differ significantly $(P<0.05)$.

${ }^{1}$ Daily infusion of phytate $\mathrm{P}$ to ileum $(\mathrm{g} / \mathrm{d}): 0=0, \times=5,3 \times=15,5 \times=25$. 
this inefficiency was due to the neutral or milk alkaline $\mathrm{pH}$ of the large intestine compared with the acidic $\mathrm{pH}$ reported ideal for the most efficient phytase activity (Yanke et al., 1999; Lan et al., 2011) and due to the very short digesta retention time in the large intestine of cows (Hecker and Grovum, 1975).

\section{Disappearance of Lower IP from the Large Intestine}

The absence of lower IP in ileal digesta indicates either that lower IP was completely degraded in the rumen and small intestine or their concentration in ileal samples was too low to be detected by HPIC. The former seems likely. In an in vitro study with pig small intestinal mucosa, phytase activity was higher toward IP3 and IP4 than IP5 and IP6 (Hu et al., 1996). In sheep fed corn- and rapeseed meal-based diets $(50 \%$ forage and $50 \%$ concentrate), daily passage of lower IP from the small intestine to the upper large intestine decreased by more than $50 \%$, indicating the ability of small intestinal mucosa to degrade lower IP. In the current study, the amount IP5 and IP4 infused daily to the ileum was different between treatment groups and fecal output of each increased with increased infusion amount (Table 4). Thus, the apparent disappearance of IP5 and IP4 from the large intestine did not differ with amount infused when expressed as percent of total supplied. The apparent disappearance of IP5 and IP 4 from the large intestine averaged 34 and $64 \%$ of total supplied, respectively. No IP3 was detected in the feces due either to complete hydrolysis in the large intestine or fecal concentration below the detection limit.

This is the first experiment where large intestinal lower IP disappearance has been investigated and observed in large ruminants. In ruminants, the disappearance of lower IP from a very small large intestinal pool may not be of nutritional significance but the quantification method may be useful to investigate lower IP disappearance from the hindgut of nonruminants.

\section{Fate of Pi in the Large Intestine}

The observed phytate disappearance from the large intestine was much lower than ruminal phytate disappearance (15 vs. $68 \%$ ), but however modest, phytate degradation would increase the pool of available $\mathrm{P}(\mathrm{Pi})$ in the large intestine. Inorganic P release from phytate degradation in the large intestine has nutritional importance only if released $\mathrm{Pi}$ is absorbed.

As expected, basal flow of Pi to the ileum was not different between treatment groups (Table 5), representing approximately $43 \%$ of total $\mathrm{P}$ flow to the ileum daily. Inorganic P in infusion solutions increased with increased phytate content because infusion solutions were prepared from a phytic acid solution that contained $\mathrm{Pi}$ as an impurity ( $\sim 18 \%$ of infused P). Despite the impurity, the amount of basal (dietary) Pi flowing to the ileum was higher than the flow of infused Pi for each treatment group.

Fecal Pi increased in a linear manner $(P=0.05)$ with increasing phytate infusion level ( 5 to $25 \mathrm{~g} / \mathrm{d}$ ) and was greater than $\mathrm{Pi}$ entering the large intestine ( $\mathrm{Pi}$ in ileal flow $+\mathrm{Pi}$ in infusion solution; Table 5). Large intestinal degradation of IP6 and lower IP likely contribute to the large intestinal pool of $\mathrm{Pi}$ but this relationship is not simple. In addition, fecal $\mathrm{Pi}$ was greater than the amount of Pi entering the large intestine as ileal flow, even in the absence of phytate infusion. The difference between the amount of $\mathrm{Pi}$ in feces and the sum of $\mathrm{Pi}$ in basal flow and infusion solution is an estimate of net Pi release from hydrolysis of IP6 and lower IP. Net disappearance of $\mathrm{Pi}$ from the large intestine makes this relationship even more complex.

Table 4. Effect of different levels of lower inositol phosphate (IP) infusion on large intestinal lower IP disappearance

\begin{tabular}{|c|c|c|c|c|c|}
\hline \multirow[b]{2}{*}{ Item } & \multicolumn{3}{|c|}{ Infusion dose ${ }^{1}$} & \multirow[b]{2}{*}{ SEM } & \multirow[b]{2}{*}{$P$-value } \\
\hline & $\times$ & $3 \times$ & $5 \times$ & & \\
\hline IP5 infused, ${ }^{2} \mathrm{~g} / \mathrm{d}$ & $0.76^{\mathrm{a}}$ & $2.44^{\mathrm{b}}$ & $3.79^{\mathrm{c}}$ & 0.08 & $<0.0001$ \\
\hline Fecal IP5, g/d & $0.5^{\mathrm{a}}$ & $1.62^{\mathrm{b}}$ & $2.29^{\mathrm{c}}$ & 0.19 & $<0.0001$ \\
\hline Net IP5 disappearance, ${ }^{3} \%$ of total supplied & 29.7 & 36.1 & 36.8 & 5.97 & 0.59 \\
\hline IP4 infused, ${ }^{4} \mathrm{~g} / \mathrm{d}$ & $0.28^{\mathrm{a}}$ & $0.91^{\mathrm{b}}$ & $1.73^{\mathrm{c}}$ & 0.04 & $<0.0001$ \\
\hline Fecal IP $4, \mathrm{~g} / \mathrm{d}$ & $0.13^{\mathrm{a}}$ & $0.35^{\mathrm{b}}$ & $0.45^{\mathrm{c}}$ & 0.05 & $<0.0001$ \\
\hline Net IP4 disappearance, ${ }^{3} \%$ of total supplied & 58.6 & 65.1 & 68.8 & 5.88 & 0.41 \\
\hline
\end{tabular}

\footnotetext{
${ }^{\mathrm{a}-\mathrm{c}}$ Values within a row with different superscripts differ significantly $(P<0.05)$.

${ }^{1}$ Daily infusion of phytate $\mathrm{P}$ to ileum $(\mathrm{g} / \mathrm{d}): \times=5,3 \times=15,5 \times=25$.

${ }^{2}$ IP5 = inositol pentaphosphate.

${ }^{3}$ Net disappearance is the difference between infused and fecal flow. Unknown is the precise fate of each IP. Disappearance of an IP may indicate partial degradation (to IP4, IP3, and so on) or complete degradation.

${ }^{4} \mathrm{IP} 4=$ inositol tetra phosphate.
} 
Table 5. Effect of ileal phytate infusion on disappearance of inorganic $\mathrm{P}(\mathrm{Pi})$ from the large intestine of 8 crossbred heifers

\begin{tabular}{|c|c|c|c|c|c|c|}
\hline \multirow[b]{2}{*}{ Item } & \multicolumn{4}{|c|}{ Infusion dose $\mathrm{e}^{1}$} & \multirow[b]{2}{*}{ SEM } & \multirow[b]{2}{*}{$P$-value } \\
\hline & 0 & $x$ & $3 \times$ & $5 \times$ & & \\
\hline Pi flow, $\mathrm{g} / \mathrm{d}$ & 2.81 & 3.70 & 4.20 & 3.19 & 0.75 & 0.54 \\
\hline $\mathrm{Pi}$ infused, $\mathrm{g} / \mathrm{d}$ & $0.00^{\mathrm{a}}$ & $0.26^{\mathrm{b}}$ & $0.79^{\mathrm{c}}$ & $1.31^{\mathrm{d}}$ & 0.03 & $<0.0001$ \\
\hline Fecal Pi, g/d & $5.80^{\mathrm{a}}$ & $7.22^{\mathrm{ab}}$ & $7.69^{\mathrm{ab}}$ & $9.30^{\mathrm{b}}$ & 0.72 & $<0.03$ \\
\hline
\end{tabular}

$\overline{\mathrm{a}-\mathrm{d}}$ Values within a row with different superscripts differ significantly $(P<0.05)$.

${ }^{1}$ Daily infusion of phytate $\mathrm{P}$ to ileum $(\mathrm{g} / \mathrm{d}): 0=0, \times=5,3 \times=15,5 \times=25$.

Reports exist of large intestinal $\mathrm{P}$ absorption in ruminants and our data also suggest this. When ileal total $\mathrm{P}$ flow and infused total $\mathrm{P}$ were used as continuous variables, the slope coefficient for total ileal $\mathrm{P}$ flow (dietary only) to feces was $0.56 \pm 0.26$ (mean $\pm \mathrm{SE}$ ), whereas the slope coefficient for infused $\mathrm{P}$ was $0.75 \pm$ 0.13. Thus $44 \%$ of ileal $\mathrm{P}$ flow and $25 \%$ of infused $\mathrm{P}$ disappeared from the large intestine. Similarly, phosphate absorption was observed from the proximal colon descendens in lambs when ligated intestinal segments were filled with $1.2 \mathrm{mM}$ phosphate solution $\left(\mathrm{HPO}_{4}{ }^{2-}+\right.$ $\mathrm{H}_{2} \mathrm{PO}_{4}^{-}$) for 30 min inside the abdominal cavity of anesthetized animals (Scharrer, 1985). Breves and Schroder (1991) observed that in sheep fed 1.0 to $4.1 \mathrm{~g}$ of $\mathrm{P} / \mathrm{d}$, net disappearance of $\mathrm{P}$ from the hindgut was 2 to $30 \%$ of total $\mathrm{P}$ entering the hindgut.

The greater relative disappearance of $\mathrm{P}$ from dietary $\mathrm{P}$ flowing to the ileum than from the pure phytate infusion (44 vs. $25 \%$ ) was likely due to the higher proportion of Pi in total P flowing to the ileum than in total $\mathrm{P}$ infused to the ileum. In sheep, the ratio of $\mathrm{Pi}$ to total $\mathrm{P}$ decreased to less than 0.2 in the lower small intestine, indicating that most of the $\mathrm{P}$ was absorbed as soluble Pi (Poppi and Ternouth, 1979). In a study conducted on cannulated sheep, the flow rate $(\mathrm{mmol} / \mathrm{h})$ of total and soluble $\mathrm{P}$ decreased by 8 and $95 \%$, respectively, from ileum to feces (Ben-Ghedalia et al., 1975). Therefore, the forms of $\mathrm{P}$ and their solubility in the digestive tract are 2 of the major factors regulating $\mathrm{P}$ absorption in the digestive tract. Ben-Ghedalia et al. (1975) observed that the solubility of $\mathrm{P}$ in sheep digesta decreased by $43 \%$ from the duodenum to the terminal ileum. The ratio of insoluble non-nucleic acid $\mathrm{P}$ to total $\mathrm{P}$ increased in the lower small intestine and proximal colon of sheep, indicating the formation of higher degree $\mathrm{P}$-complex at high $\mathrm{pH}$ in these segments of the digestive tract (Poppi and Ternouth, 1979).

The primary mechanism of phosphate absorption differs in ruminants and nonruminants. In nonruminants, the small intestinal epithelium contains $\mathrm{Na}^{+}-$ dependent phosphate transporter (Murer et al., 1994). In ruminants, however, the uptake of phosphate by intestinal epithelium occurs through an electroneutral $\mathrm{pH}$-dependent $\mathrm{H}^{+} / \mathrm{Pi}$ cotransporter, and acidic extracellular $\mathrm{pH}$ is required to maintain phosphate uptake (Shirazi-Beechey et al., 1991). The neutral $\mathrm{pH}$ in the large intestine, therefore, may limit active $\mathrm{P}$ absorption. Therefore, passive diffusion may be the predominant mechanism of $\mathrm{P}$ absorption in the large intestine at high luminal concentrations of $\mathrm{P}$. More research is needed to elucidate the mechanism of $\mathrm{P}$ absorption in the large intestine of ruminants, but this data will support mechanistic modeling efforts to improve prediction of $\mathrm{P}$ digestion, allowing more accurate estimation of $\mathrm{P}$ bioavailability in feeds.

\section{CONCLUSIONS}

Infused phytate was degraded in the large intestine of dairy heifers and this degradability was not dependent on the amount of phytate entering the large intestine. Degradation of phytate and lower IP increased the pool of large intestinal $\mathrm{Pi}$; released $\mathrm{Pi}$ disappeared partially from the large intestine. This data will support mathematical modeling approaches of predicting $\mathrm{P}$ digestion, allowing more accurate estimation of $\mathrm{P}$ bioavailability in feeds. Further study is needed with phytate from dietary sources to evaluate its flow to and degradability in the large intestine of ruminants.

\section{ACKNOWLEDGMENTS}

This project was supported by National Research Initiative Competitive Grant no. 2009-55206-05267 from the USDA Cooperative State Research, Education, and Extension Service. P. P. Ray received fellowship support from the John Lee Pratt Foundation (Blacksburg, VA).

\section{REFERENCES}

AOAC (Association of Official Analytical Chemists). 1984. Official Methods of Analysis. 14th ed. AOAC, Washington, DC.

Ben-Ghedalia, D., H. Tagari, S. Zamwel, and A. Bondi. 1975. Solubility and net exchange of calcium, magnesium and phosphorus in digesta flowing along the gut of the sheep. Br. J. Nutr. 33:87-94. 
Brautbar, N., R. Baczynski, C. Carpenter, S. Moser, P. Geiger, P. Finander, and S. G. Massry. 1982. Impaired energy-metabolism in rat myocardium during phosphate-depletion. Am. J. Physiol. 242:F699-F704.

Bravo, D., F. Meschy, C. Bogaert, and D. Sauvant. 2002. Effects of fungal phytase addition, formaldehyde treatment and dietary concentrate content on ruminal phosphorus availability. Anim. Feed Sci. Technol. 99:73-95.

Bravo, D., F. Meschy, C. Bogaert, and D. Sauvant. 2003. Phosphorus availability of oilseed meals determined by the apparent faecal digestibility technique. Anim. Feed Sci. Technol. 108:43-60.

Breves, G., and B. Schroder. 1991. Comparative aspects of gastrointestinal phosphorus metabolism. Nutr. Res. Rev. 4:125-140.

Clark, W. D., Jr., J. E. Wohlt, R. L. Gilbreath, and P. K. Zajac. 1986. Phytate phosphorus intake and disappearance in the gastrointestinal tract of high producing dairy cows. J. Dairy Sci. 69:3151-3155.

Cohen, R. D. H. 1980. Phosphorus in rangeland ruminant nutrition: A review. Livest. Prod. Sci. 7:25-37.

Dou, Z., J. D. Ferguson, J. Fiorini, J. D. Toth, S. M. Alexander, L. E. Chase, C. M. Ryan, K. F. Knowlton, R. A. Kohn, A. B. Peterson, J. T. Sims, and Z. Wu. 2003. Phosphorus feeding levels and critical control points on dairy farms. J. Dairy Sci. 86:3787-3795.

Durand, M., and S. Komisarczuk. 1988. Influence of major minerals on rumen microbiota. J. Nutr. 118:249-260.

Edwards, J. E., R. J. Wallace, B. J. Bequette, N. McKain, and N. R. McEwan. 2005. Influence of flavomycin on microbial numbers, microbial metabolism and gut tissue protein turnover in the digestive tract of sheep. Br. J. Nutr. 94:64-70.

Godoy, S., and F. Meschy. 2001. Utilisation of phytate phosphorus by rumen bacteria in a semi-continuous culture system (Rusitec) in lactating goats fed on different forage to concentrate ratios. Reprod. Nutr. Dev. 41:259-265.

Harvatine, D. I., J. E. Winkler, M. Devant-Guille, J. L. Firkins, N. R. St-Pierre, B. S. Oldick, and M. L. Eastridge. 2002. Whole linted cottonseed as a forage substitute: Fiber effectiveness and digestion kinetics. J. Dairy Sci. 85:1988-1999.

Hecker, J. F., and W. L. Grovum. 1975. Rates of passage of digesta and water absorption along large intestines of sheep, cows and pigs. Aust. J. Biol. Sci. 28:161-167.

Hoover, W. H. 1978. Digestion and absorption in hindgut of ruminants. J. Anim. Sci. 46:1789-1799.

Horst, R. L. 1986. Regulation of calcium and phosphorus homeostasis in the dairy cow. J. Dairy Sci. 69:604-616.

Hu, H. L., A. Wise, and C. Henderson. 1996. Hydrolysis of phytate and inositol tri-, tetra-, and penta-phosphates by the intestinal mucosa of the pig. Nutr. Res. 16:781-787.

Joseph, I., and R. P. Raj. 2007. Isolation and characterization of phytase-producing Bacillus strains from mangrove ecosystem. J. Mar. Biol. Assoc. India 49:177-182.

Kincaid, R. L., D. K. Garikipati, T. D. Nennich, and J. H. Harrison. 2005. Effect of grain source and exogenous phytase on phosphorus digestibility in dairy cows. J. Dairy Sci. 88:2893-2902.

Knowlton, K. F., J. H. Herbein, M. A. Meister-Weisbarth, and W. A. Wark. 2001. Nitrogen and phosphorus partitioning in lactating Holstein cows fed different sources of dietary protein and phosphorus. J. Dairy Sci. 84:1210-1217.

Komisarczuk, S., R. J. Merry, and A. B. McAllan. 1987. Effect of different levels of phosphorus on rumen microbial fermentation and synthesis determined using a continuous culture technique. Br. J. Nutr. 57:279-290.

Kwanyuen, P., and J. W. Burton. 2005. A simple and rapid procedure for phytate determination in soybeans and soy products. J. Am. Oil Chem. Soc. 82:81-85.

Lan, G. Q., N. Abdullah, S. Jalaludin, and Y. W. Ho. 2011. Purification and characterization of a phytase from Mitsuokella jalaludinii, a bovine rumen bacterium. Afr. J. Biotechnol. 10:12766-12776.

Leng, R. A. 2008. Decline in available world resources; implications for livestock production systems in Asia. Livestock Res. Rural Dev. Accessed Mar. 24, 2012. http://www.lrrd.org/lrrd20/1/leng20008. htm.
Leytem, A. B., P. Kwanyuen, P. W. Plumstead, R. O. Maguire, and J. Brake. 2008. Evaluation of phosphorus characterization in broiler ileal digesta, manure, and litter samples: ${ }^{31} \mathrm{P}-\mathrm{NMR}$ vs. HPLC. J. Environ. Qual. 37:494-500.

Louw, G. N. 1979. An evaluation of the application of stock licks in South Africa. S. Afr. J. Anim. Sci. 9:133-144.

Maki, L. R., and K. Picard. 1965. Normal intestinal flora of cattle fed high-roughage rations. J. Bacteriol. 89:1244-1249.

Marounek, M., D. Dušková, and V. Skřivanová. 2003. Hydrolysis of phytic acid and its availability in rabbits. Br. J. Nutr. 89:287-294.

Matsui, T., Y. Murakami, H. Yano, H. Fujikawa, T. Osawa, and Y. Asai. 1999. Phytate and phosphorus movements in the digestive tract of horses. Equine Vet. J. Suppl. S30:505-507.

Moody, M. L., A. J. Heinrichs, G. I. Zanton, and J. M. Daubert. 2007. Nutrient utilization of differing forage-to-concentrate ratios by growing Holstein heifers. J. Dairy Sci. 90:5580-5586.

Morse, D., H. H. Head, and C. J. Wilcox. 1992. Disappearance of phosphorus in phytate from concentrates in vitro and from rations fed to lactating dairy cows. J. Dairy Sci. 75:1979-1986.

Murer, H., D. Markovich, and J. Biber. 1994. Renal and small intestinal sodium-dependent symporters of phosphate and sulphate. J. Exp. Biol. 196:167-181.

Nelson, T. S., L. B. Daniels, J. R. Hall, and L. G. Shields. 1976. Hydrolysis of natural phytate phosphorus in digestive tract of calves. J. Anim. Sci. 42:1509-1512.

NRC. 2001. Nutrient Requirements of Dairy Cattle. 7th rev. ed. Natl. Acad. Press, Washington, DC

Park, W.-Y., T. Matsui, C. Konishi, S.-W. Kim, F. Yano, and H. Yano. 1999. Formaldehyde treatment suppresses ruminal degradation of phytate in soyabean meal and rapeseed meal. Br. J. Nutr. 81:467-471.

Park, W. Y., T. Matsui, F. Yano, and H. Yano. 2000. Heat treatment of rapeseed meal increases phytate flow into the duodenum of sheep. Anim. Feed Sci. Technol. 88:31-37.

Park, W. Y., T. Matsui, and H. Yano. 2002. Post-ruminal phytate degradation in sheep. Anim. Feed Sci. Technol. 101:55-60.

Peterson, A. B., M. W. Orth, J. P. Goff, and D. K. Beede. 2005. Periparturient responses of multiparous Holstein cows fed different dietary phosphorus concentrations prepartum. J. Dairy Sci. 88:3582-3594.

Poppi, D. P., and J. H. Ternouth. 1979. Secretion and absorption of phosphorus in the gastrointestinal tract of sheep fed on four diets. Aust. J. Agric. Res. 30:503-512.

Ray, P. P., C. Shang, R. O. Maguire, and K. F. Knowlton. 2012. Quantifying phytate in dairy digesta and feces: Alkaline extraction and high performance ion chromatography. J. Dairy Sci. 95:3248-3258

Riddell, W. H., J. S. Hughes, and J. B. Fitch. 1933. The energy metabolism of phosphorus deficient dairy cattle. Am. J. Physiol. 106:676-681.

Rounds, M. A., and S. S. Nielsen. 1993. Anion-exchange high-performance liquid-chromatography with post-column detection for the analysis of phytic acid and other inositol phosphates. J. Chromatogr. A 653:148-152.

SAS Institute. 2002. SAS User's Guide: Statistics. Version 9.2. SAS Inst. Inc., Cary, NC.

Scharrer, E. 1985. Phosphate absorption at different intestinal sites in the developing lamb. Q. J. Exp. Physiol. 70:615-621.

Selle, P. H., A. R. Walker, and W. L. Bryden. 2003. Total and phytatephosphorus contents and phytase activity of Australian-sourced feed ingredients for pigs and poultry. Aust. J. Exp. Agric. 43:475479 .

Shirazi-Beechey, S. P., R. B. Beechey, J. Penny, S. Vayro, W. Buchan, and D. Scott. 1991. Mechanisms of phosphate transport in sheep intestine and parotid gland: Response to variation in dietary phosphate supply. Exp. Physiol. 76:231-241.

Udén, P., P. E. Colucci, and P. J. Van Soest. 1980. Investigation of chromium, cerium and cobalt as markers in digesta. Rate of passage studies. J. Sci. Food Agric. 31:625-632. 
Valk, H., L. B. J. Šebek, and A. C. Beynen. 2002. Influence of phosphorus intake on excretion and blood plasma and saliva concentrations of phosphorus in dairy cows. J. Dairy Sci. 85:2642-2649.

Van Soest, P. J., J. B. Robertson, and B. A. Lewis. 1991. Methods for dietary fiber, neutral detergent fiber, and nonstarch polysaccharides in relation to animal nutrition. J. Dairy Sci. 74:3583-3597.

Viveros, A., C. Centeno, A. Brenes, R. Canales, and A. Lozano. 2000. Phytase and acid phosphatase activities in plant feedstuffs. J. Agric. Food Chem. 48:4009-4013.

Williams, P. J., and T. G. Taylor. 1985. A comparative study of phytate hydrolysis in the gastrointestinal tract of the golden hamster (Mesocricetus auratus) and the laboratory rat. Br. J. Nutr. 54:429-435.
Wise, A., and D. J. Gilburt. 1982. Phytate hydrolysis by germfree and conventional rats. Appl. Environ. Microbiol. 43:753-756.

Wu, Z., L. D. Satter, A. J. Blohowiak, R. H. Stauffacher, and J. H. Wilson. 2001. Milk production, estimated phosphorus excretion, and bone characteristics of dairy cows fed different amounts of phosphorus for two or three years. J. Dairy Sci. 84:1738-1748.

Yanke, L. J., H. D. Bae, L. B. Selinger, and K.-J. Cheng. 1998. Phytase activity of anaerobic ruminal bacteria. Microbiology 144:15651573.

Yanke, L. J., L. B. Selinger, and K.-J. Cheng. 1999. Phytase activity of Selenomonas ruminantium: A preliminary characterization. Lett. Appl. Microbiol. 29:20-25. 